UDC 629.031

V. Skalozubov, DSc, Prof.,

D. Pirkovskiy,

M. Alali,

R. Algerby

Odessa National Polytechnic University, 1 Shevchenko Ave., Odessa, Ukraine, 65044; e-mail: gntcod@te.net.ua

\title{
ALTERNATIVE METHOD OF STRENGTH ANALYSIS FOR A HEAT-POWER EQUIPMENT UNDER CYCLIC LOADS
}

\begin{abstract}
В.І. Скалозубов, Д.С. Пірковський, М. Алалі, Р. Альгербі. Альтернативний метод аналізу умов міцності при циклічних навантаженнях на теплоенергетичне обладнання. Проведений у роботі аналіз виявив надлишковий консерватизм вимог Технологічних регламентів безпечної експлуатації ВВЕР щодо максимально допустимої кількості циклів навантаження на теплоенергетичне обладнання класу безпеки В та С. Необхідність перегляду вимог до максимально допустимої кількості циклів навантаження визначається в основному тим, що різне обладнання може мати різні конструкційно-міцнісні характеристики, а в ідентичних перехідних і аварійних режимах може нести різні циклічні навантаження. Представлено альтернативний консервативний метод аналізу умов міцності при циклічних навантаженнях, який враховує в загальному випадку різницю конструкційно-міцнісних характеристик теплоенергетичного обладнання систем, важливих для безпеки, а також різницю циклічних навантажень на різне обладнання/елементи обладнання в ідентичних перехідних і аварійних режимах. На основі представленого метода проведено аналіз умов міцності на циклічні навантаження в перехідних і аварійних режимах зварних з’єднань колекторів (критичні для міцності елементи) на корпусах парогенераторів 1-го енергоблоку Південно-Української АЕС, 1-го і 2-го енергоблоків Рівненської АЕС. У результаті встановлено, що для всіх розгляданих прикладів умови міцності по циклічним навантаженням на зварні з'єднання колекторів парогенераторів виконуються. Розходження в отриманих розрахункових оцінках визначаються в основному різницею кількості циклів навантаження в аварійних режимах і в режимах порушення нормальних умов експлуатації. Розроблений альтернативний метод аналізу умов міцності при циклічних навантаженнях $\epsilon$ обгрунтованим і для інших видів теплоенергетичного обладнання - насосів, арматури і теплообмінників. Представлений метод може бути використано для вдосконалення вимог нормативних документів, які регламентують допустиму кількість циклів термічного навантаження на теплоенергетичне обладнання. Результати представленої роботи визначають обмеженість підходу роботи ядерних енергоустановок зі змінною потужністю реактора в робочих режимах експлуатації.
\end{abstract}

Ключові слова: міцність, цикл навантаження, теплоенергетичне обладнання

V. Skalozubov, D. Pirkovsky, M. Alali, R. Algerby. Alternative Method of Strength Analysis for Heat Power Equipment under Cyclic Loads. The analysis realized in the work revealed excessive conservatism of the requirements of the Technological Regulations for the WWER Safe Operation regarding the maximum allowable number of loading cycles for thermal power equipment of B and C safety class. The need to revise the requirements for the maximum allowable number of loading cycles is determined mainly by the fact that different equipment can have different structural and strength characteristics, and it can be subjected to different cyclic loads in identical transient and emergency modes. There is presented an alternative conservative method for analyzing the strength conditions under cyclic loads. It takes into account in the general case the difference in the structural and strength characteristics of the heat power equipment of safety related systems, as well as the difference in cyclic loads on different equipment/equipment elements in identical transient and emergency conditions. Based on the presented method, the strength conditions for cyclic loads on welded joints of collectors (critical for strength elements) on the cases of steam generators of South Ukrainian 1 and Rivne 1\&2 have been analysed in transient and emergency modes. As a result, it was found that the strength conditions for cyclic loading on the welded joints of the steam generator collectors are fulfilled for all the considered examples. The disagreements in the calculated estimates are determined mainly by the difference in the number of loading cycles in emergency conditions and in modes of violation of normal operating conditions. The developed alternative method for analyzing the strength conditions under cyclic loads is acceptable for other types of heat power equipment - pumps, valves and heat exchangers. The presented method can be used to improve the requirements of regulatory documents governing the permissible number of thermal loading cycles for heat power equipment. The results of the presented work determine the limited approach to the nuclear power plant operation with variable reactor power in operating conditions.

Keywords: strength, loading cycle, heat power equipment

\section{Introduction}

Norms for strength calculation of the equipment and pipelines [1] defines strength conditions under cyclic loads as ratio of the actual number of loading cycles to their admissible number:

\section{DOI: 10.15276/opu.1.60.2020.10}

(c) 2020 The Authors. This is an open access article under the CC BY license (http://creativecommons.org/licenses/by/4.0/). 


$$
\eta_{i}=N_{i} /\left[N_{0}\right]_{i},
$$

where $N_{i}$ is a total number of the loading cycles for the mode $i$ during operation (according to operation data), $\left[N_{0}\right]_{i}$ is admissible number of the loading cycles for the mode $i$ (as on the design).

Three generalized groups of the modes are usually allocated:

Transient processes under normal operation conditions (NOC),

Transient processes at the violation of normal operation conditions (VNOC),

Design accidents (DA).

In this case, strength condition for a heat power equipment (heat exchangers, pumps, and armature) of $\mathrm{B}$ and $\mathrm{C}$ groups [2] under cyclic loads:

$$
\eta(\mathrm{NOC})+\eta(\mathrm{VNOC})+\eta(\mathrm{DA}) \leq\left[a_{N}\right] .
$$

The coefficient of the cumulative fatigue damage $\left[a_{N}\right]$ is determined in 5.6 .18 [1]:

$$
\max \left\{\begin{array}{c}
a_{1}+a_{2}+a_{3} \\
a_{2}^{*}
\end{array}\right\} \leq\left[a_{N}\right],
$$

where $a_{1}$ are damages in operation loading cycles without high-frequency stress, $a_{2}$ are damages because of high-frequency stress in steady conditions, $a_{2}^{*}$ is the damage because of high-frequency stress in steady conditions leading to the greatest damage during the operation, $a_{3}$ is the sum of damages because of high-frequency stress during fluctuation cycles in the transient operational modes $a_{3}^{*}$ and for resonance frequencies $a_{3}^{* *}$ in the same cycles:

$$
a_{3}=a_{3}^{*}+a_{3}^{* *} .
$$

For the equipment of group $\mathrm{B}$, limit coefficient of the cumulative fatigue damage $\left[a_{N}\right]$ has to be no more than 0.4 , for group $\mathrm{C}$ - no more than 1 [1].

The maximum permissible number of loading cycles for NOC, VNOC and DA is given in Technical Regulations for Safe Operation (TRSO) [3].

The monograph [4] analyzes satisfiability of the strength condition (2) taking into account operation data of Rivne-1\&2 as of 2003. As a result, for Unit 1:

$$
\eta(\mathrm{NOC})=5.02, \eta(\mathrm{VNOC})=1.73, \eta(\mathrm{DA})=1 \text {. }
$$

For Unit 2:

$$
\eta(\mathrm{NOC})=4.21, \eta(\mathrm{VNOC})=2.30, \eta(\mathrm{DA})=2 .
$$

Thus, the results (5) and (6) say that strength conditions (2) are not met for heat power equipment (HPE) of B and C groups at Rivne-1\&2.

Analysis of these results [4] has revealed excess conservatism of TRSO requirements for admissible number of loading cycles and suitability of review of these requirements for the following basic reasons:

- the different equipment can have different constructional and strength characteristics, and respectively, different admissible loading cycles; modes;

- the different equipment can carry different cyclic loads in transient and accident operation

- it is necessary to consider possibility of redistribution of allowable cyclic loads in NOC, VNOC and DA. So, according to TRSO requirements, even one accident event leads to non-fulfillment of strength conditions (2) for all HPE.

Thus, review of excessive conservative TRSO requirements for admissible number of cyclic loads on HPE is reasonable. It is defines relevance of the represented work.

\section{Analysis of recent publications and problem statement}

The regulatory document [1] presents requirements for strength calculations of equipment and pipelines of nuclear power plants. However, the methodological support for the analysis of strength conditions under cyclic loads is not specified. 
The regulatory document [2] presents the requirements for the safe operation of equipment at nuclear power plants. However, methods for modelling cyclic loads on the equipment of nuclear power plants are not presented.

The work [3] presents general provisions for the degradation mechanisms and prediction of the residual life of equipment of nuclear power plants. However, the determination of the residual life by thermal loading cycles is not sufficiently considered.

The work [4] considers general approaches to ageing management and extension of the operation life of nuclear power plants. Methods for predicting the residual life by loading cycles were not considered in this work.

An actual analysis of operational data on defects in the heat exchange tubes of a steam generator is presented in [5]. These data are necessary to predict the residual life of steam generators. However, methodological support for the analysis of permissible cyclic loads is not presented.

An analysis of the failures of armature at nuclear power plants is given in [6]. It is necessary for predicting the residual life of armature. However, methodological support for the analysis of permissible cyclic loads is also not presented.

Representative databases on the reliability of HPE for various nuclear power plants are presented in [7]. However, methods for analyzing permissible cyclic loads are not given in this work.

The work [8] presents the basic requirements for methods of analysis of the strength conditions for HPE under cyclic loading. However, the methods for modelling the strength conditions were not directly considered in this work.

The above analysis of literature data defines the purpose and objectives of the proposed work.

Purpose and objectives of the study is to develop an alternative method for analyzing the strength conditions for heat power equipment under loads.

The main tasks of the work.

1. Development of the main provisions and the mathematical model of an alternative method.

2. Analysis of the results of computational modelling.

\section{Alternative method of the analysis of strength conditions for HPE under cyclic loadings}

Basic provisions and assumptions.

1. The principles of test calculations of cyclic strength according to [1] are the basis for a method. The calculations are performed for the following limit states: cyclic accumulation of plastic deformation leading to inadmissible change of the sizes or quasistatic destruction, microcrack initiation under cyclic loading.

2. Admissible design values of loading cycles $\left[N_{0}\right]$ for each group $j$ of the operational modes are determined from the maximum design value of the mode of the group or from total admissible number of loading cycles for group $j$. Each group $j$ of the operational modes is characterized by the maximum admissible value of design number of loading cycles max $\left[N_{0}\right]_{j}$.

3. According to 3.2 of Appendix 12 [1], an assessment of strength conditions for the equipment of B and C groups can integrate and reduce different types of cycles to one calculation cycle. Thus the number of calculation cycles is equal to the sum of numbers of the integrated cycles, and the allowed number of cycles $\left[N_{0}\right]$ corresponds to the maximum stress amplitude of the integrated cycles. From conservatism, the maximum stress amplitude $\left[\sigma_{a F}\right]$ can be used as the last parameter.

4. The principle of necessary conservatism for an assessment of strength conditions from loading cycles of HPE is provided by:

Admissible number of loading cycles $[N]$ corresponding to maximum stress amplitudes $\left[\sigma_{a F}\right]$ in the operation temperature range,

Stress safety factor $\left(n_{\sigma}=2\right)$ and load safety factor $\left(n_{N}=10\right)$ [1],

Maximum influence coefficients of the operational modes.

5. HPE of B and C groups from [2] is an application area of a method at NPP.

Nominal allowable stress for the elements of the equipment and pipelines loaded with internal pressure accept as minimum of the following values [1]: 


$$
[\sigma]=\min \left\{\frac{R_{m}^{T}}{n_{m}} ; \frac{R_{p 0.2}^{T}}{n_{0.2}} ; \frac{R_{m t}^{T}}{n_{m t}}\right\},
$$

where: $n_{m}=2.6, n_{0.2}=1.5, n_{m t}=1.5$.

According to 5.6.6 [1], the maximum permissible number of loading cycles for group $j$ of the modes is defined from combined equations:

$$
\left.\begin{array}{c}
\left.\left[\sigma_{a F}\right]=\frac{E^{T} e_{c}^{T}}{n_{\sigma}\left(4\left[N_{0}\right]\right)^{m}}+\frac{R_{c}^{T}}{n_{\sigma}\left[\left(4\left[N_{0}\right]\right)^{m_{e}}+\frac{1+r}{1-r}\right]}\right\}, \\
\left.\left[\sigma_{a F}\right]=\frac{E^{T} e_{c}^{T}}{\left(4 n_{N}\left[N_{0}\right]\right)^{m}}+\frac{R_{c}^{T}}{\left(4 n_{N}\left[N_{0}\right]\right)^{m_{e}}+\frac{1+r}{1-r}}\right\} \\
\left.\left[\sigma_{a F}\right]=\frac{E^{T} e_{c}^{T}}{n_{\sigma}\left(4\left[N_{0}\right]\right)^{m}}+\frac{R_{-1}^{T}}{n_{\sigma}\left(1+\frac{R_{-1}^{T}}{R_{m}^{T}} \frac{1+r}{1-r}\right)}\right), \\
{\left[\sigma_{a F}\right]=\frac{E^{T} e_{c}^{T}}{\left(4 n_{N}\left[N_{0}\right]\right)^{m}}+\frac{R_{-1}^{T}}{1+\frac{R_{-1}^{T}}{R_{m}^{T}} \frac{1+r}{1-r}}}
\end{array}\right\}
$$

where $n_{\sigma}, n_{N}$ is stress safety factor and load safety factor, respectively, $m, m_{e}$ are material characteristics, $r$ is stress ratio, $R_{c}^{T}$ is strength characteristic:

$$
R_{c}^{T}=R_{m}^{T}\left(1+1.4 \cdot 10^{-2} Z^{T}\right),
$$

$e_{c}^{T}$ is the plasticity characteristic:

$$
e_{c}^{T}=1.151 \lg \frac{100}{100-Z_{c}^{T}}-\frac{\left(\sigma_{F}^{*}\right)_{\max }-R_{p 0.2}^{T}}{2 E^{T}} .
$$

For $\left(\sigma_{F}^{*}\right)_{\max }<R_{p 0.2}^{T}$

$$
e_{c}^{T}=1.151 \lg \frac{100}{100-Z_{c}^{T}} .
$$

From Appendix 1 [1] with the guaranteed mechanical characteristics:

$$
Z_{c}^{T}=\left\{\begin{array}{c}
Z^{T}, Z^{T} \leq 50 \% \\
50 \%, Z^{T}>50 \%
\end{array}\right.
$$

If test results for static tension are known:

$$
\begin{gathered}
e_{c}^{T}=0.005 Z^{T}-\frac{\left(\sigma_{F}^{*}\right)_{\max }-R_{p 0.2}^{T}}{2 E^{T}},\left(\sigma_{F}^{*}\right)_{\max }>R_{p 0.2}^{T} ; \\
e_{c}^{T}=0.005 Z^{T},\left(\sigma_{F}^{*}\right)_{\max } \leq R_{p 0.2}^{T} .
\end{gathered}
$$

Characteristics $E, Z^{T T}, R_{m}^{T}$ are accepted equal to the minimum values in the operation temperature range taking into account ageing. Stress safety factor $n_{\sigma}=2$ and on load safety factor $n_{N}=10$.

From two values of $\left[N_{0}\right]$ determined from (8) and (9) we select the smallest one.

Exponents $m, m_{e}$ and endurance limit $R_{-1}^{T}$ are accepted according to Table 1 [1]. 
Exponents $m$ and $m_{e}$ and endurance limit $R_{-1}^{T}$

\begin{tabular}{c|c|c}
\hline Designation & $R_{m}^{T} \leq 700 \mathrm{MPa}$ & $700<R_{m}^{T} \leq 1200 \mathrm{MPa}$ \\
\hline$R_{-1}^{T}$ (for symmetric cycle) & $0.4 R_{m}^{T}$ & $\left(0.54-2 \cdot 10^{-4} R_{m}^{T}\right) R_{m}^{T}$ \\
\hline$m$ & 0.5 & $0.36+2 \cdot 10^{-4} R_{m}^{T}$ \\
\hline$m_{e}$ & \multicolumn{2}{|c}{$0.132 \lg \left[\frac{R_{m}^{T}}{R_{-1}^{T}}\left(1+1.4 \cdot 10^{-2} Z^{T}\right)\right]$} \\
\hline
\end{tabular}

For

$$
\left(\sigma_{F}\right)_{\max }<R_{p 0.2}^{\left(T_{\min }\right)} \text { and } 2\left(\sigma_{a F}\right)<\left[R_{p 0.2}^{\left(T_{\min }\right)}+R_{p 0.2}^{\left(T_{\max }\right)}\right]
$$

stress ratio is calculated from a formula

$$
r=\frac{\left(\sigma_{F}\right)_{\max }-2\left(\sigma_{a F}\right)}{\left(\sigma_{F}\right)_{\max }} .
$$

If stress ratio $r<-1$ or $r>1$, calculation accepts $r=-1$.

For $\left(\sigma_{F}\right)_{\max }>R_{p 0.2}^{\left(T_{\min }\right)}$ and $2\left(\sigma_{a F}\right)<\left[R_{p 0.2}^{\left(T_{\min }\right)}+R_{p 0.2}^{\left(T_{\max }\right)}\right]$ stress ratio is determined from a formula:

$$
r=\frac{R_{p 0.2}^{T_{\min }}-2\left(\sigma_{a F}\right)}{R_{p 0.2}^{T_{\min }}} .
$$

Amplitude of the reduced local engineering elastic stress in a cycle $i$ is found from a formula:

$$
\left(\sigma_{a F}\right)_{i}=K_{F, i}\left(\sigma_{a}\right)_{i}\left(\varphi_{s}\right)^{-1}
$$

where $\varphi_{s}$ is a cyclic strength reduction coefficient, $K_{F, i}$ is stress concentration coefficient in a cycle $i$ :

$$
K_{F}=R_{p 0.2}^{T}\left(1+0.5\left\{\left[\frac{K_{\sigma}\left(\sigma_{a}\right)}{R_{p 0.2}^{T}}\right]^{2}-1\right\} /\left(\sigma_{a}\right),\right.
$$

$R_{p 0.2}^{T}$ is a material yield strength at a specified temperature, $K_{\sigma}$ is the theoretical stress concentration coefficient determined from Appendix 3 [1].

To obtain the maximum stress amplitudes it is necessary to consider such modes when parameter changes cause the minimum and maximum stresses into the considered zone.

The allowed amplitude of engineering elastic stress for temperatures specified in 5.6 .4 [1] is determined by multiplying the calculated values by the ratio of the elastic modulus at the set temperature to the elastic modulus at a maximum temperature:

$$
\left[\sigma_{a F}\right]=\left(\sigma_{a}\right) \frac{E^{T}}{E^{T_{\max }}} .
$$

For conditions of corrosive medium, nominally admissible amplitude of elastic cyclic stresses is accepted as:

$$
\begin{gathered}
{\left[\sigma_{a F}\right]_{k}=\frac{\left[\sigma_{a F}\right]}{\tilde{\varphi}_{k}}-\text { for the pipeline, }} \\
{\left[\sigma_{a F}\right]_{k s}=\varphi_{s} \frac{\left[\sigma_{a F}\right]}{\tilde{\varphi}_{k s}}-\text { for a welded joint, }}
\end{gathered}
$$

where $\tilde{\varphi}_{k}, \tilde{\varphi}_{k s}$ is the coefficient of corrosion reduction in cyclic strength of the main metal and a welded joint defined according to requirements [1], respectively.

According to the accepted assumptions, strength condition for loading cycles on the separate equipment / element of the equipment: 


$$
\mathrm{K}_{\mathrm{A}}=\sum_{j=1}^{3} \frac{\mu_{j} N_{j}}{\left[N_{0}\right]\left(\alpha_{j}\left[\sigma_{a F}\right]\right)} \leq\left[a_{N}\right],
$$

where $\alpha_{j}$ is the coefficient depending on a type of the mode: $\alpha_{1}=1$ (NOC), $\alpha_{2}=1.2$ (VNOC), $\alpha_{3}=1.4$ (DA) [1],

$$
\mu_{j}=\left\{\begin{array}{l}
\sqrt[m]{\frac{\left\langle\sigma_{a}\right\rangle_{\max j}-R}{\left[\sigma_{a F}\right]-R}},\left\langle\sigma_{a}\right\rangle_{\max j}>R ; \\
0,\left\langle\sigma_{a}\right\rangle_{\max j} \leq R ;
\end{array}\right.
$$

$\left\langle\sigma_{a}\right\rangle_{\max j}$ is the maximum stress amplitude for group $j$ of the low-frequency modes,

$$
R=\frac{R_{-1}^{T}}{n_{\sigma}\left(1+\frac{R_{-1}^{T}}{R_{m}^{T}} \cdot \frac{1+r}{1-r}\right)}
$$

Analysis of results of calculation modelling. The vessels of steam generators of South-Ukrain-1 and Rivne-1\&2 are considered as an example of application of the obtainable strength condition (23), (24). The insert node of a primary coolant collector is a strength critical WWER steam generator element. This zone is most loaded because of the welded joints that are the increased stress concentrators. Vessel material is $10 Г Н 2 \mathrm{MФA} \mathrm{steel.}$

The generalizing transient and accident processes are:

- start of the main circulating pump of loop earlier not operating (NOC);

- loss of feedwater supply in the steam generator (VNOC);

- unfitting of the safety valve in the steam generator (PA).

Strength characteristics of metal change of heathydrodynamic parameters in transient and accident operation modes, operational data on loading cycles and failures, constructional and technical parameters and other basic data are taken from [1, 4 - 8].

Results of calculations are provided in Table 2.

Table 2

Results of calculations of strength conditions of an insert node of a collector of the steam generator

\begin{tabular}{c|c|c}
\hline NPP, Power unit & Year of operation & Strength condition \\
\hline South-Ukrain-1 & 2010 & $\mathbf{K}_{\mathrm{A}}=0.12<\left[a_{N}\right]$ \\
\hline Rivne-1 & 2003 & $\mathbf{K}_{\mathrm{A}}=0.21<\left[a_{N}\right]$ \\
\hline Rivne-2 & 2003 & $\mathbf{K}_{\mathrm{A}}=0.38<\left[a_{N}\right]$ \\
\hline
\end{tabular}

Disagreement in estimates of criterion $\mathbf{K}_{\mathbf{A}}$ are generally defined by difference of number of loading cycles in the DA and VNOC modes.

\section{Conclusions}

1. The analysis realized in the work revealed excessive conservatism of the requirements of the Technical Regulations for WWER Safe Operation regarding the maximum allowable number of loading cycles for thermal power equipment of $B$ and $C$ safety class. The need to revise the requirements for the maximum allowable number of loading cycles is determined mainly by the fact that different equipment can have different structural and strength characteristics, and it can be subjected to different cyclic loads in identical transient and emergency modes.

2. There is presented an alternative conservative method for analyzing the strength conditions under cyclic loads. It takes into account in the general case the difference in the structural and strength characteristics of the heat power equipment of safety related systems, as well as the difference in cyclic loads on different equipment/equipment elements in identical transient and emergency conditions.

3. Based on the presented method, the strength conditions for cyclic loads on welded joints of collectors (strength critical elements) on the cases of steam generators of South-Ukraine-1 and Rivne- 
1\&2 have been analysed in transient and emergency modes. As a result, it was found that the strength conditions for cyclic loading on the welded joints of the steam generator collectors are fulfilled for all the considered examples. The disagreements in the calculated estimates are determined mainly by the difference in the number of loading cycles in emergency conditions and in modes of violation of normal operating conditions.

\section{Література}

1. ПН АЭ Г-7-002-86. Нормы расчета на прочность оборудования и трубопроводов атомных энергетических установок. Москва : Энергоатомиздат, 1999. 525 с.

2. ПН АЭ Г-7-008-89 (ДНАОП 0.04-1.05-90). Правила устройства и безопасной эксплуатации оборудования трубопроводов АЭУ. М. : Госатомэнергонадзор СССР, 1990. 167 с.

3. Острейковский В.А. Старение и прогнозирование ресурса оборудования атомных станиий. Москва : Энергоатомиздат, 1994. 287 с.

4. Скалозубов В.И., Ключников А.А., Лещетная Е.С. Основы продления эксплуатаиии АЭС с ВВЭР. Чернобыль : Ин-т проблем безопасности АЭС, 2011. 384 с.

5. Зарицкий Н.С., Седнев В.А., Скалозубов В.И. Анализ эксплуатационных данных по дефектам теплообменных труб парогенераторов ВВЭР. Ядерная и радиационная безопасность. 2000. 1. C. 96-98.

6. Зарицкий Н.С., Лагута С.М., Седнев В.А., Скалозубов В.И. Анализ отказов арматуры энергоблоков Запорожской АЭС. Ядерная и радиаиионная безопасность. 2000. 2. С. 86-89.

7. Kossilov A. IAEA Co-ordinated Research Programme on the Management of Ageing of Motor Operated Isolating Valves. Proceeding of the Joint Specialist Meeting on Motor Operated Valve Issues in $\mathrm{Nu}$ clear Power Plants, Paris, France, 1994, April 25-27. 1994. P. 369-383.

8. IAEA Co-ordinated Research Program on Management of Ageing of Motor Operated Isolating Valves. Report of Stage I of Phase II. Vienna, Austria: IAEA, 1997. 125 p.

\section{References}

1. PN AE G-7-002-86. Codes of Strength Design for Equipment and Pipelines at Nuclear Power Plants. (1989). Moskva: Energoatomizdat, 525.

2. PN AE G-7-008-89 (DNAOP 0.04-1.05-90). Rules for Installation and Safe Operation of the Equipment and Pipelines of Nuclear Power Plants. (1990). Moskva: Gosatomenergonadzor SSSR, 167.

3. Ostreykovsky, V.A. (1994). Ageing and Resource Prediction of Equipment of Nuclear Power Plants. Moskva: Energoatomizdat, 287.

4. Skalozubov, V.I., Klyuchnikov, A.A., \& Leschetnaya, E.S. (2011). Fundamentals of Operation Life Extension of Nuclear Power Plants with WWER. Chernobyl: Institute for Safety Problems of Nuclear Power Plants, 384.

5. Zaritsky, N.S., Sednev, V.A., \& Skalozubov, V.I. (2000). Analysis of Operational Data on Defects in Heat Exchanger Tubes of WWER Steam Generators. Nuclear \& Radiation Safety, 1, 96-98.

6. Zaritsky, N.S., Laguta, S.M., Sednev, V.A. \& Skalozubov, V.I. (2000). Analysis of Armature Failures at Zaporizhzhya Power Units. Nuclear \& Radiation Safety, 2, 86-89.

7. Kossilov, A. (1994). IAEA Co-ordinated Research Programme on the Management of Ageing of Motor Operated Isolating Valves. Proceeding of the Joint Specialist Meeting on Motor Operated Valve Issues in Nuclear Power Plants, Paris, France, April 25-27, 369-383.

8. IAEA Co-ordinated Research Program on Management of Ageing of Motor Operated Isolating Valves. (1997). Report of Stage I of Phase II. Vienna, Austria: IAEA, 125.

Скалозубов Володимир Іванович; Skalozubov Volodymyr, ORCID: https://orcid.org/0000-0003-2361-223X

Пірковський Денис Сергійович; Pirkovskiy Denis, ORCID: https://orcid.org/0000-0002-6638-9499

Алалі Мохаммад; Alali Mohammad, ORCID: https://orcid.org/0000-0003-4052-9331

Альгерби Рабіа К. Алі; Algerby Rabia K. Ali, ORCID: https://orcid.org/0000-0001-9745-5658 